\title{
М.Т. Слобода
}

\section{ПОШИРЕНІСТЬ, СТРУКТУРА ТА ОСОБЛИВОСТІ КЛІНІЧНОГО ПЕРЕБІГУ ЗАХВОРЮВАНЬ ПАРОДОНТА В ОСІБ МОЛОДОГО ВІКУ 3 ДЕФОРМІВНИМИ ДОРСОПАТІЯМИ}

Львівський національний медичний університет імені Данила Галицького

Резюме. При одночасному стоматологічному та неврологічному обстеженні 600 осіб молодого віку встановлено різні види деформівних дорсопатій у $33 \%$, 3 яких у 104 пацієнтів (52,54 \%) діагностовано захворювання пародонта, що на $22 \%$ більше, ніж у таких без супутньої патології. Встановлено, що наявність дефор- муючих дорсопатій в осіб молодого віку сприяє достовірному збільшенню дифузних захворювань м'яких тканин пародонта і розвитку більш глибоких уражень навколозубних тканин.

Ключові слова: особи молодого віку, захворювання пародонта, деформівні дорсопатії.
Вступ. У загальній структурі стоматологічних захворювань ураження тканин пародонта посідають провідне місце [1, 3]. Особливої уваги заслуговує поширеність захворювань пародонта серед осіб молодого віку, що постійно зростає [5].

Актуальність теми зумовлена негативним впливом на стан ротової порожнини коморбідних станів, серед яких у молодому віці одним із найпоширеніших $\epsilon$ ураження опорно-рухового апарату $[2,4,11]$. Це зумовлено спільним онтогенетичним розвитком кісткової системи і щелепнолицевих тканин [13].

У дослідженнях авторів [8] доведена висока поширеність деформівних дорсопатій (кіфоз, лордоз, сколіоз, остеохондроз) в осіб молодого віку, яка становить від 12 до 30 \% на 1000 обстежених. При цьому альвеолярна кістка, як ланка кістковом'язової системи, зазнає спільні метаболічні перетворення з кістковою тканиною всього організму [13]. Остеопенія, як основний патогномонічний симптом при зазначених захворюваннях, що проявляється зниженням мінеральної щільності кісткової тканини, може бути однією з причин розвитку захворювань пародонта в молодому віці, або ускладнювати їх перебіг. Поміж тим лише в поодиноких дослідженнях [2, 6, 7, 11] вивчені питання запобігання захворюванням пародонта в осіб молодого віку з деформівними дорсопатіями. У зв'язку з цим актуальною є розробка критеріїв донозологічної діагностики схильності до розвитку захворювань пародонта в молодих осіб з деформівними захворюваннями хребта, на основі вивчення особливостей перебігу та основних клінічних діагностичних ознак хвороб навколозубних тканин у цієї категорії обстежених. Крім того, може виявитися надзвичайно актуальною рання діагностика захворювань пародонта, що допоможе запобігти поглибленню патологічного процесу, його припиненню та можливості регресу. Проте в сучасних дослідженнях недостатньо уваги приділяється окресленим питанням, що і стало предметом нашого дослідження.

Мета дослідження. Вивчити поширеність, структуру та особливості клінічного перебігу захворювань тканин пародонта в осіб молодого віку з деформівними дорсопатіями.

Матеріал і методи. Для реалізації поставленої мети проведено дослідження 600 осіб віком 19-24 роки. Дослідження проводилося на кафедрі терапевтичної стоматології ФПДО та обласній клінічній стоматологічній поліклініці ЛНМУ. Пацієнтам даної вікової категорії проводили стоматологічний огляд, а на кафедрі неврології виявляли діагноз - деформівні дорсопатії. Співвідношення за статтю у вибірці було таким: 55,33 \% жінок, 44,67 \% - чоловіків.

Для об'єктивної оцінки стану здоров'я обстежених осіб молодого віку ретельно вивчали медичну карту та висновок невропатолога, за необхідності проводили обстеження разом із терапевтом, ортопедом, травматологом та іншими фахівцями.

3 урахуванням впливу особливостей гігієнічного стану порожнини рота на перебіг захворювань тканин пародонта проведено опитування пацієнтів за спеціально розробленою стоматологічною анкетою. Розпрацьована анкета містить 22 питання, на які запропоновано від двох до шести варіантів відповідей, що дозволило виявити знання правил індивідуальної гігієни порожнини рота i, загалом, рівень стоматологічної культури обстежених пацієнтів.

У процесі опитування взяли участь 68 жінок

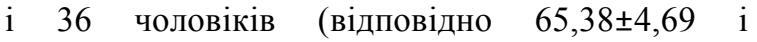
$34,62 \pm 4,69 \%$ ) із захворюваннями пародонта на тлі деформівних дорсопатій та 72 особи жіночої та 51 - чоловічої статі $(58,54 \pm 4,46$ і $41,46 \pm 4,46 \%)$ iз захворюваннями пародонта без супутньої патології хребта.

Поглиблене стоматологічне обстеження включало: збір анамнезу, огляд, зондування, перкусію, пальпацію. Виявляли захворювання твердих тканин зубів, пародонта і слизової оболонки порожнини рота.

Метою обстеження пацієнтів із захворюваннями пародонта було визначити форму, ступінь тяжкості, характер перебігу хвороби, виявлення загальних і місцевих етіологічних і патогенетичних факторів. Найбільш повна інформація дозво- 
ляла правильно поставити діагноз. Діагностику захворювань пародонта проводили відповідно до класифікації М.Ф. Данилевського [3].

3 метою визначення особливостей клінічного перебігу захворювань пародонта в осіб молодого віку із деформівними дорсопатіями (основна група) проводили порівняння з пацієнтами аналогічного вікового періоду із захворюванням пародонта без супутньої соматичної патології (порівняльна група).

Статистичну обробку даних клінічного обстеження проводили за допомогою параметричного методу $[14,15]$.

Результати дослідження та їх обговорення. Аналіз даних неврологічного обстеження 600 осіб молодого віку надав можливість виявити 198 пацієнтів з різними видами деформівних дорсопатій (що становило 33 \%). При стоматологічному обстеженні розповсюдженість карієсу зубів становила 81,5 \%, інтенсивність за індексом КПВ - 6,7, що відповідає високому рівню захворюваності та збігається з дослідженнями авторів [16] у даному регіоні. Незадовільні реставрації встановлені в 16,67 \% пацієнтів, включені дефекти зубних рядів - у 4,55 \%. Крім того, у 22,22 \% обстежених виявляли некаріозні ураження твердих тканин зубів. Натомість, виявляли високу поширеність захворювань тканин пародонта.

Поглиблене стоматологічне обстеження 198 осіб молодого віку з деформівними дорсопатіями виявило захворювання пародонта в 104 осіб $(53,53 \pm 3,56 \%)$, інтактний пародонт - у 94 осіб $(47,47 \pm 3,56 \%)$. У той же час обстеження 402 осіб молодого віку без супутньої патології виявило захворювання пародонта в $123(30,6 \pm 2,3 \%)$, клінічно здорові тканини пародонта - у 279 $(69,4 \pm 2,3 \%)$. Отже, на першому етапі дослідження встановлено достовірно вищу поширеність захворювань пародонта в молодих осіб із деформівними дорсопатіями порівняно 3 такими без супутньої патології ( $p<0,001)$, що вказує на можливий негативний вплив патології хребта.

Для визначення ролі патології хребта в розвитку захворювань пародонта проведена порівняльна оцінка структури захворювання між особами молодого віку з деформівними дорсопатіями та без таких, що наведено в таблиці. 3 наведених у таблиці даних видно, що в осіб молодого віку діагностовано різні форми гінгівіту і пародонтиту. При цьому переважали патологічні процеси в м'яких тканинах пародонта, які становили сумарно 87,8 \% спостережень у групі хворих без супутньої патології і 79,81 \% - 3 деформівними дорсопатіями. Разом з тим чітко простежувалася різниця в характері ураження навколозубних тканин залежно від наявності або відсутності патології хребта.

Аналіз матеріалів, отриманих у процесі дослідження, свідчить про те, що в молодому віці за наявності деформівних дорсопатій на 14 \% частіше діагностований хронічний дифузний катара- льний гінгівіт, ніж у таких без супутньої патології ( $<0,01)$. На відміну від дифузної форми, обмежений катаральний гінгівіт трапляється в шість разів рідше $(\mathrm{p}<0,001)$. Крім того, хронічний гіпертрофічний гінгівіт у основній групі пацієнтів діагностували удвічі рідше, ніж у порівняльній, однак внаслідок малої вибірки різниця їх значень була не достовірною ( $>>0,05)$. Слід зазначити високу поширеність уражень усього комплексу тканин пародонта в осіб молодого віку, особливо в пацієнтів із деформівними дорсопатіями, при цьому в останніх генералізований парадонтит початкового - I ступеня тяжкості встанов-

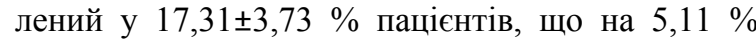
більше, ніж в осіб без супутньої патології (p>0,05). Генералізований парадонтит II ступеня тяжкості виявили у трьох осіб молодого віку 3 деформівними ураженнями хребта, що становило $2,88 \pm 1,65 \%$, у той час як у порівняльній групі дане захворювання не діагностовано в жодного пацієнта.

Отже, нами встановлено, що наявність деформівних дорсопатій в осіб молодого віку сприяє збільшенню дифузних захворювань м'яких тканин пародонта та поглибленню патологічного процесу і розвитку більш глибокого ураження всього комплексу парадонтальних тканин.

На сьогоднішній день встановлено, що контроль над рівнем індивідуальної гігієни порожнини рота $є$ ключовим фактором у профілактиці захворювань тканин пародонта $[3,5]$. У зв'язку з цим нами проведено анкетування пацієнтів обох груп дослідження.

За результатами опитування встановлено, що пацієнти молодого віку уважно слідкують за станом порожнини рота і переважна більшість 3 них регулярно чистять зуби. Однак два рази на день виконують цю процедуру $82,69 \pm 3,73$ \% пацієнтів основної групи і 66,67士4,27 \% - порівняльної. Причому в середньому $1 / 3$ чистять зуби до прийому їжі і лише $2 / 3$ - після. Опитані пацієнти не мають чіткого уявлення щодо тривалості чистки зубів і здійснюють іiі 1-2 хвилини і навіть менше. Можна допустити низьку якість очищення поверхні зубів. Крім того, 100 \% респондентів не проводять масажу ясен під час чищення зубів і майже усі не чистять язика. Це вказує на недостатній рівень усвідомленості пацієнтів про можливість самостійно уникнути додаткових факторів розвитку захворювань пародонта.

$92 \%$ пацієнтів основної групи та аналогічна кількість порівняльної користуються мануальною зубною щіткою, решта - електричною. Майже ідентична кількість хворих (приблизно 91 \%) віддають перевагу застосуванню зубної щітки середньої жорсткості. Примітно, що 84,62 $\pm 3,55$ і $78,86 \pm 3,7$ \% пацієнтів (відповідно основної та порівняльної груп) часто змінюють зубну щітку (один раз на три місяці). Проте більш ніж половина використовують одну і ту ж зубну пасту, переважно комплексну $(55,77 \pm 4,89$ i $55,28 \pm 4,5 \%$ ), орієнтуючись на рекламну інфор- 
Розповсюдженість та структура захворювань пародонта в осіб молодого віку здорспатіями та без (\%)

\begin{tabular}{|c|c|c|c|c|c|}
\hline \multirow{2}{*}{$\begin{array}{c}\text { Розповсюдженість та структура за- } \\
\text { хворювань пародонта } \\
\end{array}$} & \multicolumn{2}{|c|}{ Основна група } & \multicolumn{2}{|c|}{ Контрольна група } & \multirow[t]{2}{*}{$\mathrm{P}$} \\
\hline & абс. & $\%$ & абс. & $\%$ & \\
\hline $\begin{array}{c}\text { Із клінічно здоровими тканинами } \\
\text { пародонта }\end{array}$ & 94 & $47,47 \pm 3,56$ & 279 & $69,4 \pm 2,3$ & $<0,001$ \\
\hline Із захворюваннями пародонта: & 104 & $52,53 \pm 3,56$ & 123 & $30,6 \pm 2,3$ & $<0,001$ \\
\hline $\begin{array}{c}\text { 1.Хронічний обмежений катараль- } \\
\text { ний гінгівіт }\end{array}$ & 4 & $3,85 \pm 1,9$ & 28 & $22,76 \pm 3,8$ & $<0,001$ \\
\hline $\begin{array}{c}\text { 2.Хронічний дифузний катаральний } \\
\text { гінгівіт }\end{array}$ & 77 & $74,04 \pm 4,32$ & 74 & $60,16 \pm 4,43$ & $<0,01$ \\
\hline 3.Хронічний гіпертрофічний гінгівіт & 2 & $1,92 \pm 1,35$ & 6 & $4,88 \pm 1,95$ & $>0,05$ \\
\hline $\begin{array}{c}\text { 4.Генералізований пародонтит поча- } \\
\text { ткового - I ступеня тяжкості }\end{array}$ & 18 & $17,31 \pm 3,73$ & 15 & $12,2 \pm 2,96$ & $>0,05$ \\
\hline $\begin{array}{c}\text { 5.Генералізований пародонтит II } \\
\text { ступеня тяжкості }\end{array}$ & 3 & $2,88 \pm 1,65$ & 0 & 0 & $>0,05$ \\
\hline
\end{tabular}

мацію $(45,19 \pm 4,9$ і 41,46 $\pm 4,4$ \%) та поради друзів $(38,46 \pm 4,79$ i $39,84 \pm 4,43)$. Лише п'ята частина опитаних осіб застосовує додаткові засоби гігієни порожнини рота, переважно - зубочистки i жувальні гумки та дуже рідко - ополіскувачі. Це свідчить про недостатню стоматологічну просвіту на всіх рівнях: індивідуальному, родинному, державному тощо.

Опитування пацієнтів встановило недостатнє усвідомлення про важливість професійної гігієни порожнини рота. Цей найважливіший етап профілактики захворювань пародонта проводять 58 осіб молодого віку $(55,77 \pm 4,89 \%)$ з ураженнями тканин пародонта на тлі деформівних дорсопатій та 74 пародонтологічні пацієнти $(60,16 \pm 4,43 \%)$ - без супутньої патології. 3 них у поодиноких випадках здійснюють дані лікувально-профілактичні заходи один раз на три місяці, а в основному один раз на рік.

Зважаючи на негативний вплив шкідливих звичок на стан тканин пародонта, респондентам запропонували відповісти на питання про куріння та вживання кави і міцного чаю. При цьому $65 \%$ пацієнтів обох груп курять, а $92 \%$ - вживають каву та міцний чай.

Кровоточивість ясен та підвищена чутливість зубів при їх чищенні мають велике значення в симптоматиці захворювань пародонта [3]. Пацієнти основної групи відмічають наявність даних симптомів у $82,69 \pm 3,73 \%$ і $10,58 \pm 3,03 \%$ спосте-

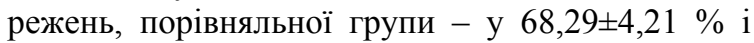
$7,32 \pm 2,36 \%$, що підтверджується об'єктивними клінічними дослідженнями. Слід відмітити, що клінічні симптоми захворювань пародонта в осіб молодого віку з деформівними дорсопатіями не відрізняються від описаної в джерелах літератури, проте окремі ознаки були більш виражені ніж у порівняльній групі. Крім того, переважна більшість пацієнтів відзначають, що виникнення за- хворювання та його рецидиви пов'язані з розвитком деформівних дорсопатій або їх загостренням.

При визначенні скарг у пацієнтів із хронічним дифузним катаральним гінгівітом з'ясовано їх відсутність у $23(29,87 \%)$ із 77 обстежених основної групи. Решта пацієнтів (80,13 \%) скаржилися на кровоточивість ясен при чищенні зубів та вживанні твердої їжі. Лише 10,30 \% скаржилися на свербіж та неприємні відчуття в яснах. При зборі анамнезу виявилося, що 16 осіб (20,78 \%) зверталися за допомогою до лікаря-стоматолога, але ефективність лікування була або відсутня, або недовготривала. Десять пацієнтів (12,99%) лікувалися самостійно за допомогою полоскань відварами та настоями трав, 26 (33,77 \%) - згідно 3 інформацією 3 інтернету. Загострення процесу хворі відмічали три і більше разів на рік. При обстеженні встановлений дифузний характер поширення процесу в $100 \%$ пацієнтів із хронічним дифузним катаральним гінгівітом. При цьому виявлено дифузну гіперемію $з$ ціанозом ясенного краю та сосочків і їх набряк. Ясенні сосочки потовщені, набряклі, пухкі, контур їх згладжений, внаслідок цього рельєф ясеннного краю змінений. При зондуванні перший ступінь кровоточивості встановлений у 67,53 \% обстежених, другий ступінь - у 14,29\%. У 28,57\% випадків спостерігали наявність несправжніх ясенних кишень, у той час як у групі порівняння - у 6,76 \% $(\mathrm{p}<0,05)$. Над'ясенні зубні відкладення частіше мінералізовані - зубний камінь $(66,23 \%)$, рідше немінералізовані - зубна бляшка $(24,68$ \%) і м'який зубний наліт (10,39 \%). Зубоясенне прикріплення не порушене в 100 \% пацієнтів основної групи з хронічним дифузним катаральним гінгівітом. При рентгенологічному дослідженні в 13 осіб (16,88 \%) виявлено остеопороз міжальвеолярних перегородок без порушення цілісності кортикальної альвеолярної пластинки, проте ця озна- 
ка в групі порівняння виявлялася лише в трьох осіб $(4,05 \%)$.

При запально-дистрофічних захворюваннях пародонта перебіг захворювання відрізнявся більш вираженою симптоматикою. Скарги на кровоточивість ясен під час чищення зубів та прийому твердої їжі виникали у 18 осіб (100\%) на генералізований пародонтит початкового - I ступеня. Неприємні відчуття, запах із рота, свербіж і парестезія ясен відмічалась у 15 пацієнтів $(83,33$ \%). Лише три пацієнти $(16,77$ \%) не пред’являли ніяких скарг. При аналізі тривалості захворювання враховували дані анамнезу. При цьому майже всі пацієнти $(94,44 \%)$ вважали себе хворими протягом одного - двох років та рецидив ураження зубоутримуючих тканин пов'язували із загостренням деформівних дорсопатій.

При об'єктивному обстеженні молодих осіб із генералізованим пародонтитом початкового - I ступеня на тлі деформівних дорсопатій виявлено симптоматику хронічного дифузного катарального гінгівіту, відкладення над- і під’ясенного зубного каменя $(88,89 \%)$, травматична оклюзія в місцях неякісно виготовлених ортопедичних конструкцій та реставрацій і зубощелепних аномалій - у 50 \%. Застійну гіперемію з синюшністю і набряком ясен спостерігали в 100 \% пацієнтів. Висота ясенного сосочка зменшується в $100 \%$ випадків. Конфігурація ясеннних сосочків змінена, деякі за рахунок набряку були у вигляді валиків. Пародонтальні кишені із серозним вмістом глибиною до 2мм виявлені в 14 осіб (77,78 \%), до 3 мм - у 4 осіб (22,22\%). Кровоточивість ясен I ступеня виявлена в 13 пацієнтів цієї групи (72,22 \%), II ступеня - у 5 (27,78 \%). Патологічну рухомість зубів не спостерігали. При рентгенологічному дослідженні помірно виражений остеопороз губчастої речовини міжальвеолярних перегородок і потоншення або резорбція кортикального шару їх вершин виявлено в семи обстежених $(38,89$ \%). Нерівномірну горизонтальну резорбцію альвеолярного відростка в межах 1/4-1/3 його висоти - в 11 (61,11 \%). Натомість у пацієнтів групи порівняння дані показники становили відповідно $80 \%$ і $20 \%$.

При збільшенні тяжкості захворювання i розвитку генералізованого пародонтиту II ступеня в осіб молодого віку з дорсопатіями найчастішими скаргами були: біль в яснах $(33,33$ \%), кровоточивість (100\%), відчуття свербежу, оніміння, ломоти в яснах $(66,67 \%)$, запах із рота $(100 \%)$, рухомість зубів $(66,67 \%)$. Анамнестичні дані аналогічні таким при початковому - I ступені. При огляді зазначеної групи хворих виявляли симптоми хронічного дифузного катарального гінгівіту у двох пацієнтів (66,67 \%), симптоми хронічного гіпертрофічного гінгівіту, набрякову форму - в одного пацієнта (33,33 \%). У всіх пацієнтів спостерігали наявність над- і під'ясенних зубних відкладень, велика кількість м'якого зубного нальоту, оголення шийок зубів від 3 до 6 мм. Глибина пародонтальних кишень 3-6 мм із серозно-гнійним вмістом виявлено у двох осіб, 68 мм - в одного. Травматичну оклюзію визначали в $100 \%$ спостережень, рухомість зубів І ступеня - у 66,67 \%, II ступеня - в 33,33\%, в останніх між зубами діастеми і треми. При рентгенологічному дослідженні встановлено дифузний остеопороз кісткової тканини, змішаний тип резорбції міжальвеолярних перегородок у межах від 1/3 1/2 їх висоти.

Незначну кількість становили пацієнти 3 хронічним обмеженим катаральним гінгівітом (чотири особи). Клінічна симптоматика локалізованого ураження тканин пародонта в осіб молодого віку з дорсопатіями не відрізняється від такої при дифузних. Різниця в тому, що патологічний процес був обмежений ділянками декількох зубів та в усіх спостереженнях виявляли місцеві етіологічні чинники захворювання: неповноцінні реставрації у двох пацієнтів - $50 \%$; патологія прикусу - в 1 (25\%), травмування ясенного краю ортодонтичною конструкцією - в 1 (25\%). Набрякова форма хронічного катарального гінгівіту, що встановлена в осіб молодого віку з дорсопатіями, зумовлена поганою гігієною ротової порожнини і характеризувалася наступними ознаками: наявність над'ясенного м'якого зубного нальоту, у тому числі зубної бляшки майже на усіх зубах, набряк і застійна гіперемія ясен та їх кровоточивість; несправжні зубоясенні кишені глибиною до Змм із серозним вмістом, відсутність рентгенологічних змін у альвеолярному відростку щелепи.

\section{Висновки}

1. Одночасне стоматологічне і неврологічне обстеження 600 осіб молодого віку виявило різні види деформівних дорсопатій у $33 \%$ пацієнтів (198 осіб), з яких у 104 паціснтів (52,54 \%) діагностували захворювання тканин пародонта. На відміну від них хвороби навколозубних тканин із 402 обстежених осіб молодого віку без уражень хребта встановлені в 123 (30,6 \%). Це свідчило про достовірно вищий рівень уражень тканин пародонта при деформівних дорсопатіях та вплив супутньої патології на їх інтенсивність у молодому віці.

2. У структурі захворювань пародонта в осіб молодого віку переважали генералізовані ураження тканин (хронічний дифузний катаральний гінгівіт і генералізований пародонтит), що встановлені в 78,23\% осіб із деформівними дорсопатіями і в 72,36 \% - без супутньої патології хребта.

3. Особливістю структури хвороб пародонта в осіб молодого віку з деформівними ураженнями хребта $є$ істотно вища поширеність хронічного дифузного катарального гінгівіту $(\mathrm{p}<0,01)$ та аналогічно нижча - хронічного обмеженого катарального гінгівіту ( $<0,001)$ порівняно з пацієнтами без супутньої патології, а також збільшення генералізованого пародонтиту початкового - I ступеня та поява генералізованого пародонтиту II ступеня. Це підтверджувало обтяження патологічно- 
го процесу та його поглиблення при деформівних дорсопатіях.

Встановлено недостатній рівень знань осіб молодого віку про значення індивідуальної гігієни порожнини рота у профілактиці захворювань пародонта: 32,69 \% опитаних чистять зуби протягом 1 хвилини, 29,81 \% - 2 хвилин, 37,5 \% - менше 1 хвилини; 92,3 \% застосовують лише мануальну зубну щітку і 52,77 \% - комплексні зубні пасти, які обирають, орієнтуючись на рекламу $(45,19 \%)$ або поради друзів $(38,46 \%) ; 100 \%$ - не здійснюють масажу ясен під час чищення зубів, а $97,12 \%$ - не чистять язика; 18,27 \% - взагалі не використовують додаткових засобів гігієни, а 60,58 \% - рідко, переважно зубочистки та жувальні гумки; 44,23\% - не проводять професійної гігієни порожнини рота, решта - переважно раз на рік (70,68 \%); курять - 65,38 \%, каву і міцний чай вживають 92,31\%.

Клінічний перебіг захворювань пародонта в осіб молодого віку з деформівними дорсопатіями не відрізнявся від такого в обстежених без супутньої патології. Однак окремі ознаки захворювань пародонта (наявність несправжніх пародонтальних кишень, остеопороз міжальвеолярних перегородок) більш виражені, ніж у групі порівняння. Виникнення та загострення уражень зубоутримуючих тканин пов'язано із деформівними захворюваннями хребта.

Перспективою подальших досліджень $\epsilon$ вивчення стану гігієни порожнини рота та фізико-хімічних властивостей ротової рідини в осіб молодого віку з деформівними дорсопатіями.

\section{Література}

1. Вагнер В.Д. Значение стоматологического здоровья для качества жизни пациента / В.Д. Вагнер, К.Г. Гуревич // Пробл. стоматол. - 2013. - № 2. - С. 21-26.

2. Галкіна О.П. Особливості клініки та лікування генералізованого парадонтиту у підлітків зі сколіозом: автореф. дис. на здобуття наук. ступ. канд. мед. наук: спец. 14.01.22 “Стоматологія” / О.П. Галкіна. - Одеса, 2011. $-19 \mathrm{c}$.

3. Заболотний Т.Д. Запальні захворювання пародонта / Т.Д. Заболотний, А.В. Борисенко, Т.І. Пупін. - Львів: ГалДент, 2013. -233 с
4. Завербна Л.В. Рання діагностика дистрофії пародонта в осіб молодого віку / Л.В. Завербна, О.Л. Личковська // Імплантологія. Пародонтологія. Остеологія. 2012. - № 2. - С. 76-80.

5. Клинико-рентгенологическая диагностика заболеваний зубов и пародонта у детей и подростков: учеб.пособие / Л.А. Хоменко, Е.И. Остапко, Н.В. Биденко. - К.: Книга плюс, 2004. - 200 с.

6. Клиническая оценка состояния тканей пародонта у детей с патологией опорно-двигательного аппарата / О.В. Деньга, Д.Д. Жук, В.С. Иванов [и др.] // Вісн. стоматол. - 2009. - № 3 (68). - С. 95-99.

7. Клінічна оцінка стану твердих тканин зубів та рівня гігієни порожнини рота у дітей з патологією опорнорухового апарату / О.В.Дєньга, В.С. Іванов, Д.Д. Жук [и др.] // Вісн. стоматол. - 2010. - № 1 (70). - С. 63-66.

8. Кудрявцева Т.В. Динамика заболеваемости, молодежи и антропологических характеристик у студентов; СПбГМУ им. акад. И.П. Павлова / Т.В. Кудрявцева, И.Н. Никифорова, Н.В. Сивас // Biomedical and Biosocial'Anthropology, 2007. - C. 26-31.

9. Лепский В.В. Стоматологический статус соматически здоровых молодых людей Украины / В.В.Лепский, Т.В. Колесник, О.В. Деньга // Вісн. стоматол. - 2011. № 4. - C. 76-79.

10. Модина Т.Н. Состояние здоровья подростков и парадонтологический статус / Т.Н. Модина, Е.В. Мамаева // Педиатрия. - 2008. - Т.87, №2. - С. 131-134.

11. Самойленко А.В. Распространенность стоматологических заболеваний у детей со сколиозом / А.В. Самойленко, В.О. Дрок // Соврем. стоматол. - 2011. - № 1 (57). - C. 116-119.

12. Смоляр Н.І. Уражуваність карієсом зубів, дітей хворих на сколіоз / Н.І. Смоляр, М.О. Шаран, А.А. Колісніченко // Укр. стоматол. альманах. - 2011. - № 5. C. 71-73.

13. Поворознюк В.В. Костная система и заболевания пародонта / Поворознюк В.В., Мазур И.П. - Книга плюс, 2004. -448 c.

14. Приходський О.О. Медична статистика / О.О. Приходський, А.О. Голяченко, Л.М. Морар. - Тернопіль Лілея, 2000. - $140 \mathrm{c}$.

15. Реброва О.Ю. Статистический анализ медицинских данных. Применение пакета программ STATISTICA: учеб. пособие / О.Ю. Реброва. - [2-е изд.]. - М.: Медиа Сфера, 2003. $-312 \mathrm{c}$.

16. Хоменко Л.О. Стан твердих тканин постійних зубів у різних за екологічною ситуацією регіонах України / Л.О. Хоменко, О.І Остапко, Ю.М. Ткачук // Нов. стоматол. - 2007. - № 1 (50). - С. 87-91.

\section{РАСПРОСТРАНЕННОСТЬ, СТРУКТУРА И ОСОБЕННОСТИ КЛИНИЧЕСКОГО ТЕЧЕНИЯ ЗАБОЛЕВАНИЙ ПАРОДОНТА У ЛИЦ МОЛОДОГО ВОЗРАСТА С ДЕФОРМИРУЮЩИМИ ДОРСОПАТИЯМИ}

\section{М.Т. Слобода}

Резюме. При одновременном стоматологическом и неврологическом обследовании 600 человек молодого возраста установлены различные виды деформирующих дорсопатий в $33 \%$, из которых в 104 пациентов $(52,54 \%)$ диагностировано заболевание пародонта, что на $22 \%$ больше, чем в таких без сопутствующей патологии. Установлено, что наличие деформирующих дорсопатий у лиц молодого возраста способствует достоверному увеличению дифузных заболеваний мягких тканей пародонта и развитию более глубоких поражений околозубных тканей.

Ключевые слова: лица молодого возраста, заболевания пародонта, деформирующие дорсопатии.

\section{PREVALENCE, STRUCTURE AND CLINICAL COURSE OF PERIODONTAL DISEASES IN YOUNG PEOPLE WITH DEFORMING DORSOPATHIES}

\section{M.T. Sloboda}

Abstract. In the overall structure of dental lesions periodontal diseases take the top spot. Of particular note is the prevalence of periodontal diseases among young people, which is growing. Actuality caused by negative impact of comorb- 
id conditions on oral cavity, from witch at a young age is one of the most common lesions of the musculoskeletal system.

Aim of the study. To study the prevalence, structure and clinical course of periodontal diseases in young persons with deforming dorsopathies.

Materials and methods. Dental examination was held in 600 people aged 19-24 years, deforming dorsopathies was diagnosed at the Department of Neurology. For an objective assessment of the health of young people was thoroughly studied medical card and conclusion of neurologist, in special cases conducted together with the therapeut, orthoped, traumatology doctor and other experts.

Research results. Dental and neurological examination of 600 young people revealed different types of deforming dorsopaties in $33 \%$ of patients (198 people), of which in 104 patients $(52,54 \%)$ diagnosed periodontal diseases. In contrast, periodontal diseases from 402 young people without deforming dorsopathies was in 123 patients (30,6\%). This indicated significantly higher levels of periodontal diseases in patients with deforming dorsopaties and impact of comorbidity on their intensity at a young age.

In the structure of periodontal diseases in young age dominated generalized lesions (chronic generalized catarrhal gingivitis and generalized periodontitis), established in 78,23 \% of people with deforming dorsopathies and $72,36 \%$ without comorbidity.

The feature of the structure of periodontal diseases in young persons with deforming dorsopathies is significantly higher prevalence of chronic generalized catarrhal gingivitis $(\mathrm{p}<0,01)$ and similarly lower - localised chronic catarrhal gingivitis $(\mathrm{p}<0,001)$ compared with patients without comorbidity, and increasing generalized periodontitis initial - I degree and the emergence of generalized periodontitis II degree. This is confirmed by burdening of pathological process and its deepening in deforming dorsopaties.

It was established insufficient knowledge of young people about the importance of individual oral hygiene in the prevention of periodontal diseases, $32,69 \%$ of respondents brush their teeth for 1 minute, $29,81 \%-2$ minutes $37,5 \%$ - less than 1 minute; 92,3\% used only of manual toothbrush and 52,77\% - comprehensive toothpaste, which selected from advertising $(45,19 \%)$ or the advice of friends (38,46\%); $100 \%$ - didn't massage gums while brushing teeth, and $97,12 \%$ didn't clean the tongue; $18,27 \%$ didn't use additional hygiene, and 60,58 \% - rarely, mostly toothpicks and gum; $44,23 \%$ didn't conduct professional oral hygiene, the rest - mostly 1 per year $(70,68 \%)$; smokers $-65,38 \%$, coffee and strong tea consumed $-92,31 \%$.

Conclusion. The clinical course of periodontal diseases in young persons with deforming dorsopathies have no different from that without comorbidity. However, some signs of periodontal disease (presence of false periodontal pockets, osteoporosis) are more pronounced than in the comparison group. The emergence and exacerbation of periodontal diseases associated with deforming dorsopathies.

Key words: young people, periodontal diseases, deforming dorsopathies.

Danylo Halytsky National Medical University (Lviv)

Рецензент - доц. О.В. Митченок

Buk. Med. Herald. - 2015. - Vol. 19, № 4 (76). - P. 163-168

Надійшла до редакції 08.07.2015 року

(C) М.Т. Слобода, 2015 